\title{
Characterization of Scaling Power of Tiznit Region Waters
}

\author{
Said Ben-Aazza, Abdallah Hadfi, M’barek Belattar, Naima Hafid, Ali Driouiche* \\ Team "Materials and Physico-Chemistry of Water", Faculty of Science, IBN ZOHR University, Agadir, Morocco \\ Email: *driouiche@yahoo.fr
}

How to cite this paper: Ben-Aazza, S. Hadfi, A., Belattar, M., Hafid, N. and Driouiche, A. (2017) Characterization of Scaling Power of Tiznit Region Waters. Journal of Water Resource and Protection, 9, 339-344. https://doi.org/10.4236/jwarp.2017.94022

Received: January 26, 2017

Accepted: March 4, 2017

Published: March 7, 2017

Copyright $\odot 2017$ by authors and Scientific Research Publishing Inc. This work is licensed under the Creative Commons Attribution International License (CC BY 4.0).

http://creativecommons.org/licenses/by/4.0/ (c) (i) Open Access

\begin{abstract}
The phenomenon of scaling is particularly observed in the regions of Morocco which exploit groundwater. The region of Tiznit uses these waters, partly, for its domestic and industrial needs. The major problem of the use of this water is, besides its medium quality, the clogging of the pipes. The aim of this work is to study the phenomenon of water scaling in Tiznit region using the means of thermodynamic and kinetic analyses. The physicochemical analysis of this region's waters shows that their contents of calcium and magnesium are very high. The hydrometric title is situated between $18^{\circ} \mathrm{F}$ and $64^{\circ} \mathrm{F}$. The alkalinity varies from $22^{\circ} \mathrm{F}$ to $82^{\circ} \mathrm{F}$. The classification of waters of this region for assessing the risk of clogging, according to their hardness, shows that $80 \%$ of these waters are hard waters. The kinetic characterization of scaling power of drinking water in this region was conducted using the method LCGE which also proved the scaling character of these waters.
\end{abstract}

\section{Keywords}

Scaling Power, Calcium Carbonate, Clogging, LCGE, Tiznit

\section{Introduction}

The water resources of the city of Tiznit and the neighboring rural communes are very limited. The exhaustion of water requirements of this area is made from the dam of Youssef Ibn Tachfine located on one of the arms of Oued Massa, from Reggada source located in the platform of Ouled Jerrar, and from Talaint wells, distanced respectively of $32.8 \mathrm{~km}, 20 \mathrm{~km}$ and $24 \mathrm{~km}$ away from the city of Tiznit. The exploitation of the Reggada source water began in 1996. Two thirds of this water is used to supply hundreds of small villages surrounding Tiznit with drinking water. The waters of Youssef Ibn Tachfine dam and Talaint wells are mainly intended for the feeding of Tiznit city. During the water flow, the phenomenon 
of scaling in the pipelines transporting these waters is observed mainly under the effect of a degasification of the water and the very low solubility limit of calcium carbonate. Thus, we are interested in this work to study this phenomenon of scaling, which is a priority in our research works, and in finding an adequate solution to eradicate this problem [1] [2].

To take account of the variation, according to the seasons of the physicochemical water quality of the Tiznit region, we have followed up the quality of these waters during one year (from August 2014 to July 2015) from several sampling points. A classification of these waters has been done, at first, for the thermodynamic evaluation of chemical clogging of pipeline of these waters. We have then, in a second, selected five representative samples of the water of this region for the kinetic characterization of the scaling power of these waters by the method of controlled degassing "LCGE".

\section{Experimental Techniques}

The kinetic characterization of the scaling power of drinking water of Tiznit region was studied by means of the method LCGE [2] [3] [4] [5]. This method aims at provoking the precipitation of the calcium carbonate by a degassing (displacement of the calco-carbonic balance in the sense of the formation of the calcium carbonate) of the studied water. The statement of the $\mathrm{pH}$ values and the concentration of $\mathrm{Ca}^{2+}$ ion in the course of time, consequently, allow making a description of the kinetics of precipitation according to the following reaction:

$$
\mathrm{Ca}^{2+}+2 \mathrm{HCO}_{3}^{-} \longrightarrow \mathrm{CaCO}_{3(\mathrm{~s})}+\mathrm{CO}_{2(\mathrm{~g})}+\mathrm{H}_{2} \mathrm{O}
$$

The statement of the $\mathrm{pH}$ values and the concentration of $\mathrm{Ca}^{2+}$ ion in the course of time, consequently, allow making a description of the kinetics of precipitation.

The physicochemical characterization of the studied waters was carried out using standardized methods:

- The ions calcium, magnesium and hydrogen carbonates were determined by the volumetric method.

- The chloride and sulfate ions were respectively determined by Mohr's method and the gravimetric method.

- The ions $\mathrm{NH}_{4}^{+}$were determined by colorimetry.

- The $\mathrm{NO}_{3}^{-}$ions were determined by measuring UV/visible spectrophotometry.

- The atomic absorption was used for the determination of concentrations of ions $\mathrm{Na}^{+}$and $\mathrm{K}^{+}$.

\section{Results and Discussion}

\subsection{Physico-Chemical Characterization of Waters of Tiznit Region}

In order to reflect the variation of the physicochemical water quality of Tiznit region, according to the seasons, at the consumer level, we carried out a monitoring of quality of these waters during one year (from August 2014 to July 2015). The 
measured physical and chemical parameters are shown in Table 1 . It is about the $\mathrm{pH}$, temperature $(\mathrm{T})$, the dry residue (DR), conductivity $(\sigma)$, the total hardness (TH) and the total alkalinity (TAC).

We first note that the values obtained for the different parameters are in accordance with the Moroccan standard for the quality of drinking water [6].

The total hardness fluctuates between a maximum value of $64^{\circ} \mathrm{F}(640 \mathrm{mg} / \mathrm{L}$ of $\left.\mathrm{CaCO}_{3}\right)$ and a minimum value of $18^{\circ} \mathrm{F}\left(180 \mathrm{mg} / \mathrm{L}\right.$ of $\left.\mathrm{CaCO}_{3}\right)$. The total alkalinity varies between $82^{\circ} \mathrm{F}$ and $22^{\circ} \mathrm{F}$. Four samples of the studied waters were selected for the characterization of scaling power. They are from Reggada source (Water R), Talaint well (Water T), Youssef Ibn Tachfine dam (water D), and the water reservoir (Water $(\mathrm{R}+\mathrm{D}+\mathrm{T})$ ) where water of the Reggada source mixes with that of Youssef Ibn Tachfine dam and that of Talaint well. The results of the physicochemical analysis of these waters are reported in Table 2 and Table 3.

The examination of physicochemical analysis results show that, except for water of Youssef Ibn Tachfinedam, the contents of calcium and magnesium of these different waters are very high and consequently they are very hard [7].

The concentrations of the hydrogen carbonate ions of these waters are also very important in causing the precipitation of calcium carbonate, highly dissoluble salt, which is responsible for the most common problems of scaling [8] [9]. Consequently, the scaling potential of these waters will be very high because the reaction of precipitation of the calcium carbonate is directly related to the contents of calcium and hydrogen carbonates [10] [11] [12].

Table 1. Minimum and maximum values of the measured parameters.

\begin{tabular}{ccccccc}
\hline & $\mathrm{TH}\left({ }^{\circ} \mathrm{F}\right)$ & $\mathrm{TAC}\left({ }^{\circ} \mathrm{F}\right)$ & $\mathrm{T}\left({ }^{\circ} \mathrm{C}\right)$ & $\mathrm{pH}$ & $\mathrm{DR}(\mathrm{mg} / \mathrm{L})$ & $\sigma(\mu \mathrm{S} / \mathrm{cm})$ \\
\hline Minimum values & 18 & 22 & 15.5 & 7.10 & 336 & 450 \\
maximum values & 64 & 82 & 23.1 & 7.95 & 1310 & 1457 \\
\hline
\end{tabular}

Table 2. Physical parameters for different samples of drinking water of the Tiznit region.

\begin{tabular}{rccc}
\hline & $\mathrm{pH}$ & Temperature $\left({ }^{\circ} \mathrm{C}\right)$ & Conductivity $(\mu \mathrm{S} / \mathrm{cm})$ \\
\hline Water R & 7.10 & 21.3 & 878 \\
Water T & 6.90 & 20.9 & 1457 \\
Water D & 7.50 & 21.4 & 472 \\
Water (R + D + T) & 7.50 & 23.1 & 1002
\end{tabular}

Table 3. Chemical parameters for different samples of drinking water of the Tiznit region.

\begin{tabular}{|c|c|c|c|c|c|c|c|c|c|c|}
\hline & $\begin{array}{l}\mathrm{TH} \\
\left({ }^{\circ} \mathrm{F}\right)\end{array}$ & $\begin{array}{l}\text { TAC } \\
\left({ }^{\circ} \mathrm{F}\right)\end{array}$ & $\begin{array}{c}\mathrm{Ca}^{2+} \\
(\mathrm{mg} / \mathrm{L})\end{array}$ & $\begin{array}{c}\mathrm{Mg}^{2+} \\
(\mathrm{mg} / \mathrm{L})\end{array}$ & $\begin{array}{c}\mathrm{Na}^{+} \\
(\mathrm{mg} / \mathrm{L})\end{array}$ & $\begin{array}{c}\mathrm{K}^{+} \\
(\mathrm{mg} / \mathrm{L})\end{array}$ & $\begin{array}{c}\mathrm{NH}_{4}^{+} \\
(\mathrm{mg} / \mathrm{L})\end{array}$ & $\begin{array}{c}\mathrm{Cl}^{-} \\
(\mathrm{mg} / \mathrm{L})\end{array}$ & $\begin{array}{c}\mathrm{NO}_{3}^{-} \\
(\mathrm{mg} / \mathrm{L})\end{array}$ & $\begin{array}{c}\mathrm{SO}_{4}^{2-} \\
(\mathrm{mg} / \mathrm{L})\end{array}$ \\
\hline Water R & 46.44 & 81 & 99.40 & 52.59 & 40 & 1.81 & 0.03 & 95.85 & 1.78 & 10.72 \\
\hline Water T & 62.60 & 67 & 151.82 & 60.12 & 103.42 & 2.59 & 0.00 & 333.70 & 4.69 & 31.67 \\
\hline Water D & 18.20 & 24 & 47.13 & 15.65 & 18 & 0.80 & 0.01 & 46.15 & 0.11 & - \\
\hline Water $(\mathrm{R}+\mathrm{D}+\mathrm{T})$ & 52.66 & 67 & 109.25 & 45.64 & 48.46 & 2.18 & 0.00 & 223.65 & 2.31 & 21.84 \\
\hline
\end{tabular}




\subsection{Kinetic Study of Scaling Power}

For the kinetic study of the scaling power of selected waters, we adopted the "LCGE" method to determine the $\mathrm{pH}$ and the time of germination ( $\mathrm{pHg}$ and $\mathrm{Tg}$ ) of calcium carbonate. Figure 1 and Figure 2 show successively the evolution of $\mathrm{pH}$ and $\mathrm{TCa}$ according to time at $25^{\circ} \mathrm{C}$ obtained by the "LCGE" method for the water samples selected.

At the beginning of degassing, the $\mathrm{pH}$ continues to increase. During this increase of the $\mathrm{pH}$, no evolution of the $\mathrm{Ca}^{2+}$ concentration is noticeable. This metastability state ceases abruptly at the time Tg which we define as the practical time of germination and manifested on the $\mathrm{pH}$ that accuses a fall. The beginning of

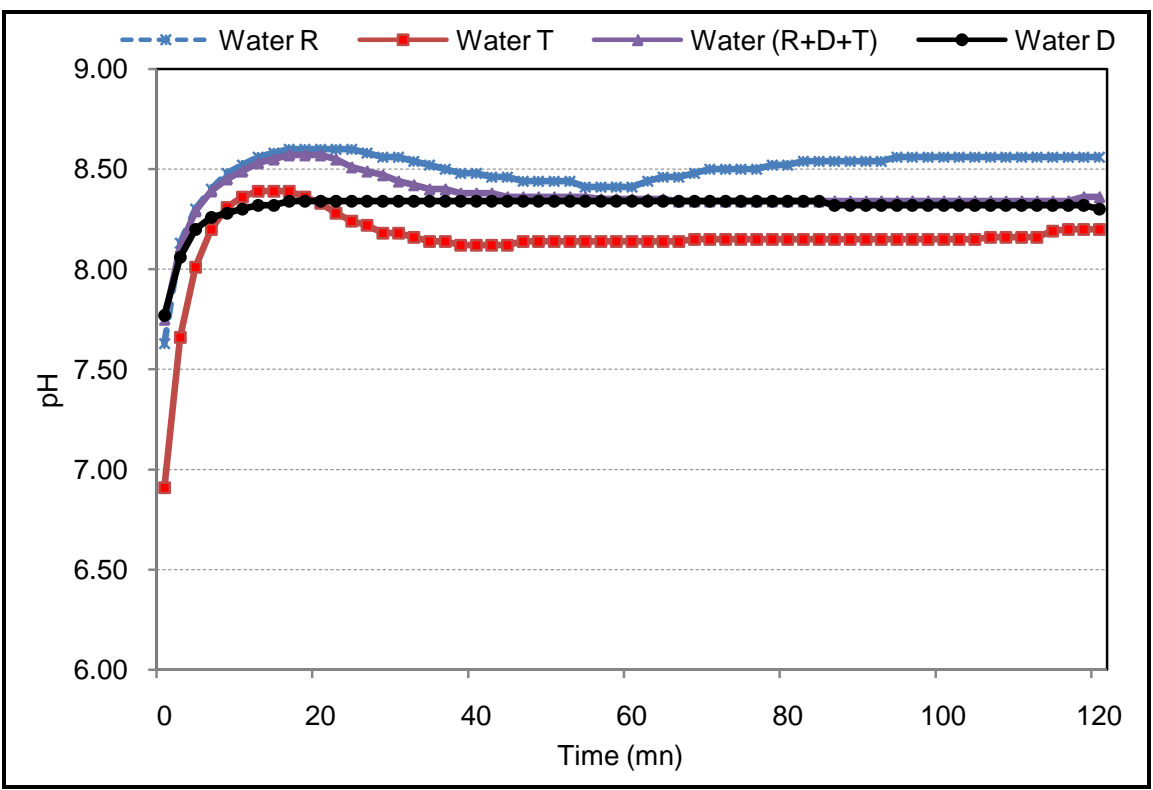

Figure 1. Curves of $\mathrm{pH}$ according to the time of water of the Tiznit region.

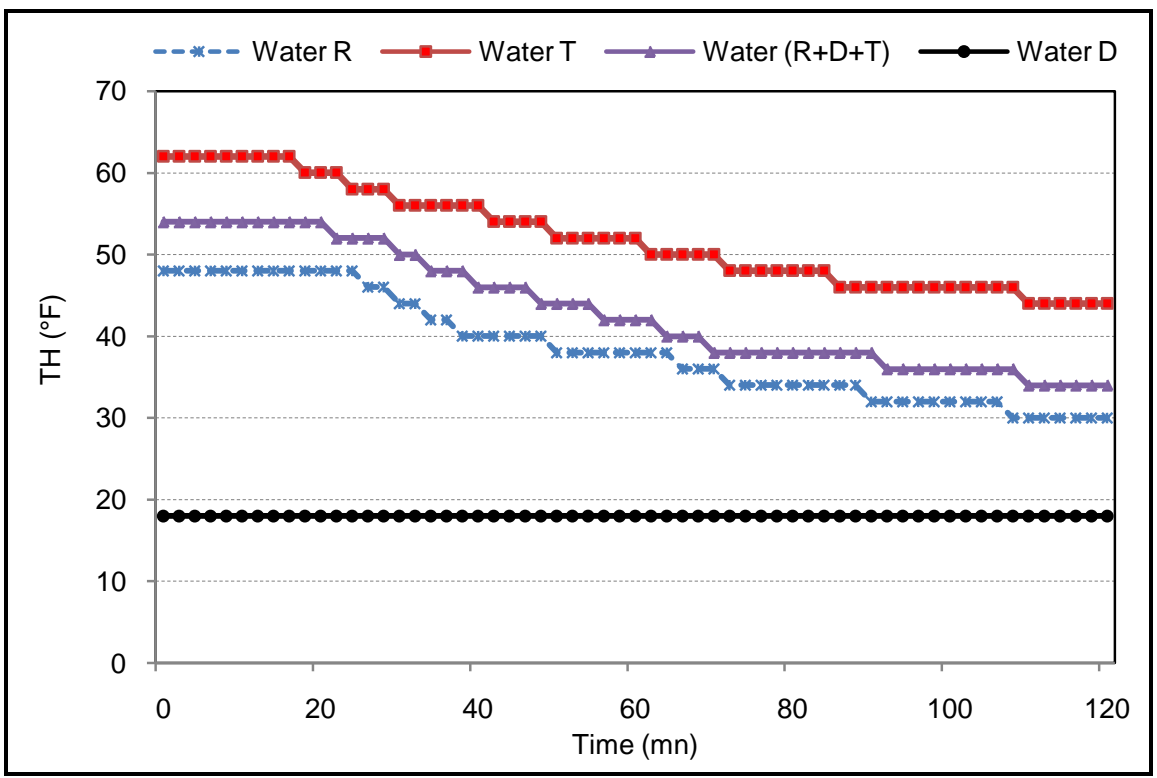

Figure 2. Curves of TCa according to the time of the waters of the Tiznit region. 
Table 4. Time of germination $(\mathrm{Tg})$ and $\mathrm{pH}$ of germination $(\mathrm{pHg})$ of drinking waters of Tiznit area.

\begin{tabular}{ccccc}
\hline & Water R & Water T & Water $(\mathrm{R}+\mathrm{D}+\mathrm{T})$ & Water D \\
\hline $\mathrm{pHg}$ & 8.58 & 8.36 & 8.55 & - \\
$\mathrm{Tg}(\mathrm{mn})$ & 26 & 18 & 22 & - \\
\hline
\end{tabular}

precipitation is also accused by a decrease of the concentration calcium ion (Figure 2). This fall of $\mathrm{pH}$ can be related to the proton release when the precipitation of calcium carbonate begins according to the following reaction:

$$
\mathrm{Ca}^{2+}+\mathrm{HCO}_{3}^{-} \longrightarrow \mathrm{CaCO}_{3(\mathrm{~S})}+\mathrm{H}^{+} .
$$

This mechanism of formation of $\mathrm{CaCO}_{3}$ from $\mathrm{HCO}_{3}^{-}$and of $\mathrm{Ca}^{2+}$ was advanced by Roques et al. [4]. This decrease in $\mathrm{pH}$ continues up to the time $\mathrm{t}$ which depends on the quality of the studied water and beyond which it starts to rise slowly. At this time $t$, the rate of precipitation, according to the last reaction, has slowed sufficiently and the degassing speed becomes higher than the release rate of proton $\mathrm{H}^{+}$.

At the time $\mathrm{Tg}$ we define the $\mathrm{pHg}$ as the $\mathrm{pH}$ of practical germination. The values of these parameters deduced from curves "LCGE" are given in Table 4. It should be noted that the scaling power of the waters of Tiznit region follows the sequence:

$$
\text { Water } \mathrm{T}>\text { Water }(\mathrm{R}+\mathrm{D}+\mathrm{T})>\text { Water } \mathrm{R} \text {. }
$$

The experimental results obtained by the method "LCGE" after 2 hours for water of Youssef Ibn Tachfine dam show no fall in $\mathrm{pH}$ or TCa according to time and, consequently, there is no precipitation of calcium carbonate.

\section{Conclusion}

The physico-chemical quality of drinking waters of Tiznit region varies with the seasons. The total hardness fluctuates between $18^{\circ} \mathrm{F}$ and $64^{\circ} \mathrm{F}$. The total alkalinity ranges from $22^{\circ} \mathrm{F}$ to $82^{\circ} \mathrm{F}$. The characterization of the scaling power of the waters of this region was studied by means of the LCGE method and led to conclude that, except for the water of Youssef Ibn Tachfinedam, all other waters are scaling water.

\section{References}

[1] Belattar, M., Ben-Aazza, S., Aba-Aaki, R., Hadfi, A., Hafid, N., Boukbir, L. and Driouiche, A. (2016) Contribution to the Study of Hot Water Scaling Phenomenon in the South of Touristic Area in Agadir City. Journal of Water Resource and Protection, 8, 1035-1043. https://doi.org/10.4236/jwarp.2016.812082

[2] Hadfi, A., Ben-Aazza, S., Belaatar, M., Hafid, N. and Driouiche, A. (2015) Study of the Inhibitor Scaling Effect of the Agricultural Water by a Phosphate Fertilizer. Journal of Water Resource and Protection, 7, 1234-1241. https://doi.org/10.4236/jwarp.2015.715100

[3] Roques, H. (1964) Study of the Kinetics of Precipitation of Calcium Carbonate. Doctoral Thesis, Paul Sabatier University, Toulouse. 
[4] Dedieu, L., Hort, C., Domingues, A.M., Rola, M. and Roques, H. (1994) Contribution to the Study of the Scaling Phenomenons. General Points and the L.C.G.E. Method of Study. Tribune de Peau, 47, 3-19.

[5] Hort, C., Domingues, A.M., Rabut, C. and Roques, H. (1995) Contribution to the Study of Scaling Phenomena. 2nd Part: The Kinetics of Crystal Growth. Tribune de Peau, 48, 31-46.

[6] NM 03.7.001 (2006) Moroccan Standard for the Quality of Water for Human Consumption. Official Bulletin No. 5404.

[7] Tabouche, N. and Achour, S. (2004) Study of Groundwater Quality of the Eastern Region of the Algerian Northern Sahara. Larhyss Journal, 3, 99-113.

[8] Hadda, S.R. (2009) Contribution to the Assessment and Inhibition of Hard Water Scaling Power by Several Methods. Magister Thesis, Mentouri University, Algeria.

[9] Menzri, R. and Ghizellaoui, S. (2012) Chronoamperometry Study of the Inhibition of Groundwater Scaling Deposits in Fourchi. Energy Procedia, 18, 1523-1532. https://doi.org/10.1016/j.egypro.2012.05.169

[10] WHO (2004) Guidelines for Drinking-Water Quality. 3rd Edition, Vol. 1, World Health Organization, Geneva.

[11] Hafid, N., Belaatar, M., Ben-Aazza, S., Hadfi, A., Ezahri, M. and Driouiche, A. (2015) Characterization of Scale Formed in Drinking Water and Hot Water Pipes in the Taliouine Downtown-Morocco. American Journal of Analytical Chemistry, 6 , 677-686. https://doi.org/10.4236/ajac.2015.68065

[12] Driouiche, A., Hadfi, A., Eddaoudi, H. and El Hadek, M. (2013) Study of the Chemical Inhibition of the Scaling of Large Agadir Water. MATEC Web of Conferences, 3, Article ID: 01044. https://doi.org/10.1051/matecconf/20130301044

Submit or recommend next manuscript to SCIRP and we will provide best service for you:

Accepting pre-submission inquiries through Email, Facebook, LinkedIn, Twitter, etc. A wide selection of journals (inclusive of 9 subjects, more than 200 journals)

Providing 24-hour high-quality service

User-friendly online submission system

Fair and swift peer-review system

Efficient typesetting and proofreading procedure

Display of the result of downloads and visits, as well as the number of cited articles

Maximum dissemination of your research work

Submit your manuscript at: http://papersubmission.scirp.org/

Or contact jwarp@scirp.org 